\title{
GSTM4 wt Allele
}

National Cancer Institute

\section{Source}

National Cancer Institute. GSTM4 wt Allele. NCI Thesaurus. Code C105665.

Human GST M4 wild-type allele is located in the vicinity of 1 p13.3 and is approximately 9 $\mathrm{kb}$ in length. This allele, which encodes glutathione S-transferase Mu 4 protein, is involved in xenobiotic metabolism. 